\title{
Det oversete argument
}

\section{C.S. Peirces "The Neglected Argument for the Reality of God"}

\author{
Stud.theol. \\ Martin Ravn
}

\begin{abstract}
The article presents American semiotician Charles Sanders Peirce's 1908 essay "The Neglected Argument for the Reality of God" which has been viewed as notoriously difficult and obscure. The article is primarily concerned with giving an account of the three stages that constitute Peirce's argument, as well as giving an interpretation of their inter-relation (a much discussed problem in Peirce scholarship). Conclusively, the article reviews the relevance of the theological views presented in Peirce's argument by sketching how Peirce's idea of God draws the current discussion of the relationship between methodological naturalism and normativity into the terrain of philosophical theology.
\end{abstract}

Key words: Concepts of God - Semiotics - C.S. Peirce - Logic - Naturalism - Pragmatism - Normativity.

Målet med denne artikel er at give en fremstilling af Charles Sanders Peirces (1839-1914) essay "The Neglected Argument for the Reality of God" fra 1908. Fremstillingen består af to dele. I den første del fremstilles hvert af de tre trin, som udgør Peirces argument, mens den anden del giver et originalt bud på sammenhængen imellem dem (hvilket er et omdiskuteret problem i Peirce-forskningen). Afslutningsvis skitserer artiklen det teologiske potentiale i Peirces essay ved at perspektivere til, hvordan Peirces gudsbegreb bringer den aktuelle diskussion om forholdet mellem metodologisk naturalisme og normativ viden ind på religionsfilosofiens område.

\section{Introducerende bemærkninger}

Den amerikanske filosof Charles Sanders Peirce (1839-1914) er primært kendt for eftertiden for sin vidtrækkende og komplekse semio- 
tiske teori. Imidlertid så Peirce selv sit livsværk som udviklingen af et helt, sammenhængende filosofisk system, som med logisk stringens omfattede alle aspekter af virkeligheden. Peirce var ikke bleg for at sammenligne sit filosofiske systembyggeri med G.W.F. Hegels. Receptionshistorien af Peirces værk vidner dog om, at helheden i Peirces system i den første del af det tyvende århundrede blev nedtonet til fordel for læsninger af enkeltstående bidrag (mest udpræget af semiotisk art), som til gengæld nød en stigende anerkendelse indenfor så forskelligartede videnskaber som fysik og lingvistik. ${ }^{1}$ Men Peirces filosofiske system har et metafysisk grundlag og en række metafysiske implikationer, som ofte blev negligeret. Ikke mindst af religionsfilosofien, som på trods af Peirces eksplicitte beskæftigelse med emner af religionsfilosofisk relevans (blandt andet Guds virkelighed), var påfaldende sen til få øjnene op for potentialet i Peirces værk. Først i 1980'erne udkom den første grundige undersøgelse af Peirces gudsbegreb, ${ }^{2}$ og de bedste redegørelser for det religionsfilosofiske potentiale i Peirces metafysik er, med en enkelt undtagelse, først udkommet i det seneste årti. ${ }^{3}$

De grundlæggende bestemmelser i Peirces tanker om metafysik er udslag af hans generelle syn på videnskab. ${ }^{4}$ Ifølge Peirce er det, som gør en disciplin til en videnskab dens evne til at frembringe falcificerbare hypoteser (bemærk, at vi med Peirce befinder os årtier før Karl Poppers prægning af denne tese). Det kan metafysiske udsagn lige så godt som for eksempel matematiske udsagn (som også er abstrakte), og det er det, 'metafysikeren' må bestræbe sig på. Men det har den metafysiske tænkning historisk ikke gjort. Peirce anklager tænkere som Leibniz og Kant for at have behandlet metafysisk tænkning a priorisk, hvilket bl.a. har udmøntet sig i teser som den, at naturlove er ubetvivlelige og uforklarlige. Men en lov er par excellence det, som behøver en grund. ${ }^{5}$ Metafysikken er som sagt ikke mere abstrakt end

1. Se Peder Voetmann Christiansens introduktion til Charles Sanders Peirce, Kosmologi og metafysik. Fem artikler fra tidsskriftet The Monist, 1891-93 (København: Gyldendal 1996), 7-8.

2. Donna Orange, Peirce's Conception of God: A Developmental Study (Bloomington: Indiana University Press 1984).

3. Det drejer sig om Michael L. Raposa, Peirce's Philosophy of Religion (Bloomington: Indiana University Press 1989), Hermann Deuser, Gottesinstinkt: Semiotische Religionstheorie und Pragmatismus (Tübingen: Mohr Siebeck 2004), Andrew Robinson, God and the World of Signs (Leiden and Boston: Brill 2010).

4. Disse introducerende bemærkninger bygger i høj grad på Peder Voetmann Christiansens forbilledligt klare indledning til Peirce, 1996.

5. Charles Sanders Peirce, "The Architecture of Theories" i The Essential Peirce. Selected Philosophical Writings. Volume 1(1867-1893), eds. Nathan Houser and Christian Kloesel (Bloomington: Indiana University Press 1992). Herefter forkortet som EP 1. 
matematikken eller logikken. Men selvom matematikken og logikken er abstrakte, så har de betydning for konkrete gøremål. Et eksempel kunne være tyngdeloven, der, selvom den er matematisk abstrakt, har en yderst konkret betydning. Ligeså med metafysikken. Men til forskel fra matematikken og logikken, så beskæftiger metafysikken sig videnskabeligt med ontologien. Det vil sige, at metafysikken er videnskaben om væren. Ligesom matematikkens rolle er at sætte det abstrakte i relation til det konkrete, så er metafysikkens opgave først og fremmest at redegøre for væren i henseende til det abstrakte og sætte det i relation til noget konkret. Dette er let nok, når det drejer sig om ting, der har individuel eksistens (fx udsagnet: katten er på bordet). Det er imidlertid mere vanskeligt, når det drejer sig om generelle eller abstrakte udsagn, som for eksempel det, at nødvendighed går forud for tilfældighed. Hverken tilfældighed eller nødvendighed har konkret, individuel eksistens. Man kan ikke se eller røre nødvendighed eller tilfældighed. Alligevel, siger Peirce, giver det ikke mening at hævde, at de ikke er reelle. Eksistens er altså knyttet til konkrete individer, mens realitet handler om abstrakte idéer eller principper.

Disse overvejelser over metafysikkens status ligger til grund for "The Neglected Argument for the Reality of God", 6 som siden sin oprindelige udgivelse i tidsskriftet The Hibbert Journal i 1908 har været anset som et gådefuldt værk. ${ }^{7}$ Essayet hører, som udgivelsesåret antyder, til den sene del af Peirces forfatterskab. Derfor skal det læses under hensyntagen til de begreber, koncepter og ikke mindst den idiosynkratiske sprogbrug, der er typiske for Peirces senværk: Kort fortalt, så lykkedes det omkring 1900 Peirce at nå det mål, han havde stræbt efter fra slutningen af 1880'erne og igennem 1890'erne: At forene de forskellige dele af sin filosofi i ét sammenhængende system. Dette system refererede han i begyndelsen til som en deskriptiv fænomenologi (phenomenology), i øvrigt fuldstændig uafhængigt af Edmund Husserl, hvis samtidige begyndende brug af samme begreb Peirce tilsyneladende intet kendte til. Senere ændrede han navnet på sit filosofiske system til det noget mindre mundrette phaneroscopy (EP2, 403), et system, hvis betydning han som sagt gerne sammenlignede i betydning med filosofihistoriens store systembyggerier (EP1, xviif).

6. Charles Sanders Peirce, "The Neglected Argument for the Reality of God" (1908), i The Essential Peirce. Selected Philosophical Writings Volume 2. (1893-1913), ed. The Peirce Edition Project (Bloomington: Indiana University Press 1998), 434450. - Herefter forkortet som EP 2.

7. Den holdning, at essayet er vanskeligt at forstå, dunkelt og enigmatisk finder man blandt andet hos udgiverne af den nuværende standardudgave af Peirces vigtigste skrifter, EP 2, 434. Se også Douglas R. Anderson, "Three Appeals in Peirce’s Neglected Argument" i Transactions of the Charles S. Peirce Society, Summer 1990, Vol. 26 Issue 3. 
Phaneroscopien hviler på tre grundantagelser, som er nødvendige at kende for at forstå Peirces ærinde med "The Neglected Argument for the Reality of God", om end Peirce kun berører dem indirekte i artiklen: 1) doktrinen om musement, 2) den metafysiske påstand, at alle fænomener kan reduceres til manifestationer af førstehed, andethed og tredjehed (firstness, secondness, thirdness). 3) Peirces teori om kontinuitet og sammenhæng, synechism. I denne fremstilling vil jeg vise, præcis hvordan disse elementer spiller en rolle både for indholdet såvel som for strukturen af "The Neglected Argument for the Reality of God”.

\section{Den treleddede struktur i "The Neglected Argument for the Reality of God"}

I sit efterskrift beskriver Peirce "The Neglected Argument for the Reality of God", ikke som ét argument, men som tre: "a nest of three arguments" (EP 2, 443). Man kan med C.F. Delaney sige, at den del af argumentet, som Peirce kalder The Humble Argument, konstituerer kernen af essayets argumentation, mens de to andre dele er refleksioner herover. ${ }^{8}$ Peirce beskriver sit "Humble Argument" som en art meditation over idéen om Gud:

The first argument is that entirely honest, sincere, and unaffected, because unprepence, meditation upon the Idea of God, into which the Play of Musement will inevitably sooner or later lead, and which by developing a deep sense of adorability of that Idea, will produce a Truly religious Belief in His Reality and His nearness (EP 2, 446).

I dette citat introducerer Peirce begrebet Play of Musement (på dansk: grublespillet) ${ }^{9}$. Musement er en form for refleksion, der ikke er styret af regler, men i stedet skal forstås som en art meditation (EP2, 43738). Det gudsbegreb (Idea of God), som Musement før eller siden vil føre til, er, at egennavnet Gud dækker over den nødvendige væren, som er universets skaber: "The word 'God' so 'capitalized' (as we Americans say) is the definable proper name, signifying ens necessarium: in my belief Really creator of three Universes of Experience" (EP 2, 434).

Med "Three Universes of Experience" hentyder Peirce til den grundlæggende metafysiske hypotese, at alle universelle fænomener

8. Se C. F. Delaney, "Peirce on the Hypothesis of God" i Transactions of the Charles S. Peirce Society 28 (1992), 730.

9. Sådan oversættes begrebet i introduktionsafsnittet til Peirce (1996), 13. 
kan reduceres til manifestationer af enten førstehed (firstness), andenhed (secondness) eller tredjehed (thirdness). Førstehed indbefatter kvalitet og potentialitet, andethed reaktion/modstand og "brute fact" og tredjehed lovmæssighed, repræsentation og mediation. ${ }^{10}$

Inden Peirce påbegynder sin egentlige udredning af dette Humble Argument, finder han det nødvendigt at klargøre to ting. For det første uddyber han, hvad han forstår ved argument, henholdsvis ved argumentation. Ved førstnævnte forstås et generelt begreb, der indikerer en given tankerække, der udvikler sig mod en given tro eller overbevisning. Ved sidstnævnte forstås en mere specifik idé, som bygger på allerede formulerede præmisser og bevæger sig mod en eksplicit konklusion.

Kernen i "The Neglected Argument for the Reality of God" er the Humble Argument, som er et argument, idet det i sin kerne er en påstand og altså ikke bygger på en allerede givet præmis. Dertil kommer essayets yderligere to dele, som hver fremhæver nogle bestemte aspekter af the Humble Argument og derfor er argumentationer. Den første argumentation har at gøre med, hvorfor et praktisk engagement $\mathrm{i}$ the Humble Argument ikke kan adskilles fra tro (eng. belief) på det. Det kalder Peirce the Practical Aspect (forkortet $P A$ ). Den anden argumentation har at gøre med den logiske metodologi, der ligger til grund for the Humble Argument. Den kalder Peirce the Logical Aspect (forkortet $L A)$. Denne struktur kan illustreres således:

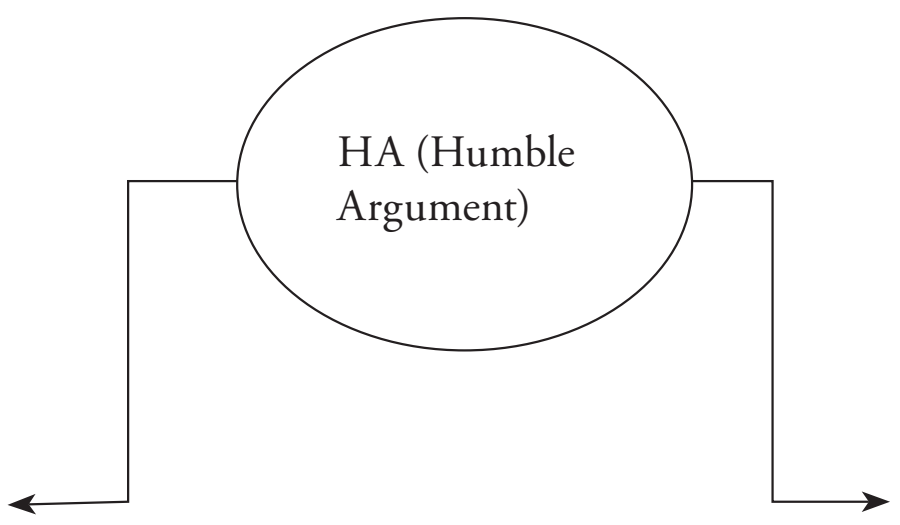

PA (Practical Aspect)

LA (Logical Aspect)

(Neglected Argument Proper)

Det andet tema, som Peirce behandler, inden han begynder sin egentlige udredning af the Humble Argument er, hvordan det er muligt at lave argumenter vedrørende Gud. Selve grundpillen i Peirces epi-

10. Se essayet "Nomenclature and Divisions of Triadic Relations, As Far as They Are Determined" for uddybelser, EP 2, 289-300. 
stemologiske teori er, at mennesket har en fundamental, naturgiven evne til at forstå virkeligheden:

"The mind of man is strongly adopted to the comprehension of the world" (EP 1, 180).

"It is certain that the only hope of retroductive reasoning ever reaching the truth is that there may be some natural tendency toward an agreement between the ideas which suggest themselves to the human mind and those which are concerned in the laws of nature."11

"All human knowledge, up to the highest flight of science, is but the development of our inborn, animal instincts." 12

I "The Neglected Argument for the Reality of God" forbindes denne påstand med idéen om Guds virkelighed (reality ${ }^{13}$ ), idet Peirce påstår, at hvis Gud er virkelig, så ville det være plausibelt at antage, at Gud har skabt universet på en sådan made, at hans virkelighed ville være åbenbar for hans skabning (Delaney, 1992, 730). Og på grund af Guds vilje til at åbenbare sig for sin skabning, er mennesket $i$ besiddelse af en latent religiøsitet, eller latent tro på Gud: "a latent tendency toward belief in God which is a fundamental ingredient of the soul" (EP 2, 447).

Efter disse forberedende bemærkninger kan Peirce påbegynde sit Humble Argument. Kernen i the Humble Argument er musement. Musement er som sagt defineret ved at være en uregelbundet form for tænkning, eller slet og ret: "pure play" (EP 2, 436). Hermed forstår Peirce en tænkning, der ikke er underlagt de samme regler for logisk ræsonnement, som ellers er påkrævet for stringent tænkning. Netop spekulation over sådanne reglers beskaffenhed er noget, som Peirce viede en stor del af sit forfatterskab til. Kort fortalt, så argumenterer Peirce for, at rationel, logisk tænkning er baseret på den trefoldige

11. Charles Sanders Peirce, Collected Papers Volume 1, red. Charles Hartshorne og Paul Weiss (Cambridge: Harvard University Press 1933), \$81.

12. Charles Sanders Peirce, Collected Papers Volume 2, red. Charles Hartshorne og Paul Weiss (Cambridge: Harvard University Press 1933), \$754.

13. Peirce definerer begrebet 'reality' således: "Real' is a word invented in the thirteenth century to signify having Properties, i.e. characters sufficing to identify their subject, and possessing these whether they be anywise attributed to it by any single man or group of men, or not.

Thus, the substance of a dream is not Real, since it was such as it was, merely in that a dreamer so dreamed it; but the fact of the dream is Real, if it was dreamed; since if so, its date, the name of the dreamer, etc., make up a set of circumstances sufficient to distinguish it from all other events" (CP 2, 435). 
struktur af a) at introducere en forklarende hypotese via abduction, ${ }^{14}$ b) at uddybe denne ved deduktion og c) enten at bekræfte eller benægte den forklarende hypotese ved induktion. Musement er karakteriseret ved, at den kun finder sted i den første kategori og altså ikke bevæger sig videre til det deduktive og det induktive stadium. Det betyder, at musement er tættere beslægtet med meditation end med rationel tænkning (EP 2, 439). At det er indenfor musement, at gudshypotesen kan opstå, er vigtigt for den videre progression af Peirces essay. Det engagement, som en fri tænken over gudshypotesen fører til, skal nemlig ses som et instinktivt gensvar til hypotesen og derfor ikke som en rationel spekulation. Musement er en hjertesag, ikke en sag for fornuften.

Således beskrives altså den metode, som Peirce gør brug af, når han spekulerer over gudshypotesen. Men hvad er det, som musement bliver brugt til at tænke over?

Som vi så i det ovenstående, så er grundpåstanden i the Humble Argument, at egennavnet Gud skal forstås som skaberen af "de tre universer" (EP 2, 440). Det bidrager til essayets dunkelhed, at Peirce ikke præciserer, at hvad han har i tankerne med "the three universes of experience", er det samme som han andensteds refererer til som førstehed, andethed og tredjehed (eng. firstness, secondness, thirdness). Peirce refererede første gang til sin metafysiske teori om, at alle fænomener kan reduceres til manifestationer af enten førstehed, andethed og tredjehed i slutningen af 1880'erne, og påstanden udvikledes yderligere i fire artikler i tidsskriftet The Monist i begyndelsen af 1890 'erne. Det gudsbegreb, der plæderes for i the Humble Argument er således, at egennavnet Gud refererer til skaberen af den potentialitet, der er manifest i førstehed, den virkelighed, der er manifest i andethed og den lovmæssighed, mediation og repræsentation, der er manifest i tredjehed. Det er dog ikke alene disse tre kategorier, der beskrives som genstand for musement $\mathrm{i}$ "The Neglected Argument for the Reality of God". Der er et bestemt aspekt af dem, der er særligt dragende for den person, der er engageret i musement, og dette aspekt er sammenhængen imellem førstehed, andethed og tredjehed. Dette bringer os til det tredje aspekt af Peirces senfilosofi, som er en nødvendig forudsætning for at forstå "The Neglected Argument for the Reality of God": Peirce kalder sin doktrin om sammenhæng og

14. Ifølge Peirce, så mangler deduktion og induktion evnen til at kunne introducere nye, forklarende hypoteser. De er derfor ikke tilstrækkelige inferenskategorier og må forudgribes af abduktioner, som er forklarende hypoteser: "Observe that neither Deduction nor Induction contributes the smallest positive item to the final conclusion of the inquiry. They render the indefinite definite: Deduction explicates; Induction evaluates: that is all” (EP 2, 443). 
kontinuitet synechism, og svarende til påstanden om, at universet basalt set består af manifestationer af førstehed, andethed og tredjehed, mener Peirce, at universet er gennemtrængt af synechisme. Sammenhængen og kontinuiteten mellem førstehed, andethed og tredjehed bliver tydelig for den, der engagerer sig i musement:

Let the Muser, for example, after well appreciating, in its breadth and depth, the unspeakable variety of each Universe, turn to those phenomena that are of the nature of homogeneities of connectedness in each; and what a spectacle will unroll itself (EP 2, 438). ${ }^{15}$

Gud skal altså ikke alene forstås som universets skaber, men også som den, dets sammenhæng og kontinuitet grunder i. Laver vi igen et sideblik til Peirces øvrige senværk, så bliver det åbenbart, at den føromtalte evne, som det er Peirces epistemologiske grundpåstand, at mennesket har, er betinget af netop sammenhæng og kontinuitet, synechism. ${ }^{16}$ Universet er ifølge Peirce gennemtrængt af tegn ("the universe is perfused with signs"), ${ }^{17}$ og universet er derfor betydningsbærende og betydningsskabende og i den forstand levende. Af forståelsen af universet som basalt set konstitueret af førstehed, andethed og tredjehed følger en betydningsforståelse, som afspejler denne struktur:

A Sign, or Representamen, is a First which stands in such a genuine triadic relation to a Second, called an Object, as to be capable of determining a Third, called its Interpretant, to assume the same triadic relation to its Object in which it stands itself to the same Object. The triadic relation is genuine, that is, its three members are bound together by it in a way that does not consist in any complexes of dyadic relations (Collected Papers II, \$273).

I "The Neglected Argument for the Reality of God" får denne fundamentalsemiotiske virkelighedsbeskrivelse en dimension af formålsrettethed, fordi idéen om Gud som skaber nødvendigvis, ifølge Peirce, må medføre en idé om, at Gud har et formål med sin skabning: "the

15. Delaney parafraserer dette således: "In musement the mind is allowed to wander freely with the result that the original fascination or impression grows into a wonder as to the homogeneities and connectedness amid the infinite variety of each universe and into a consideration of the homogeneities and connections between the different universes. In particular, the growth whereby the later stages are for in the earlier ones is striking in all three universes" (Delaney, 1992, 731).

16. Dette er uddybet i min prisopgave: Martin Ravn, C. S. Peirce: A Theological Account With Special Regard to the Idea of God. Det Teologiske Fakultet, Københavns Universitet 2012, 30-57.

17. Charles Sanders Peirce, Collected Papers Volume 5, red. Charles Hartshorne og Paul Weiss (Cambridge: Harvard University Press 1934), \$449. 
hypothesis [of God] will lead to our thinking of features of each Universe as purposed" (EP 2, 439-40).

Dette er indholdet af den grundantagelse, som Peirce kalder for the Humble Argument, et beskedent argument. Fokuserer man udelukkende på denne del af Peirces essay, kunne man være tilbøjelig til at give ham ret i den beskrivelse. Hvad er her at komme efter andet end en dristig hypotese? Men det er netop pointen med "The Neglected Argument for the Reality of God", at denne del ikke står alene, og vi skal i det følgende se på de to argumentationer, som følger det argument, vi indtil nu har behandlet.

\section{Det praktiske aspekt af the Humble Argument}

Den første argumentation på grundlag af the Humble Argument omhandler som tidligere nævnt det praktiske aspekt, som the Humble Argument medfører. Grundpåstanden er her den, at den tænkning om hypotesen om Gud (musement), som blev beskrevet i essayets første del, ikke kan adskilles fra tro på Gud:

The second of the nest is the argument which seems to me to have been 'neglected' by writers upon natural theology, consisting in showing that the humble argument is the natural fruit of free meditation, since every heart will be ravished by the beauty and adorability of the Idea [of God], when it is so pursued (EP 2, 446).

Påstanden hviler på den antagelse, at gudshypotesen nødvendigvis må have en praktisk dimension, fordi idéen om Gud som universets skaber medfører et 'livsideal', "an ideal of life" (EP 2, 439).

For at forstå nøjagtigt, hvad der er på færde her, må vi endnu engang fæstne opmærksomheden på de idéer, der er helt centrale for tankegangen i "The Neglected Argument for the Reality of God", men som forbliver eksplicit ubeskrevne i selve essayet: Det er en central påstand i Peirces semiotiske epistemologi, at meningen eller betydningen i en given semiotisk sammenhæng ikke skal findes i den måde, hvorpå et tegn henviser til et objekt, men i den tolkning, som dette afstedkommer. Hvor vi i den kontinentale semiologiske tradition fra F. Saussure, R. Barthes, etc. er vant til at tænke, at betydning er noget, der opstår mellem noget betegnet og noget betegnende (signifié, signifiant), så indfører Peirce en tredje instans i sin semiotiske model. Denne tredje instans er den eller det, der aflæser tegnet, og denne instans kalder Peirce den semiotiske interpretant. Den semiotiske interpretant er defineret som den adfærd, sædvane eller handlemåde, som en given tegnlæsning medfører, og det er netop det område, som 
essayets anden del omhandler. Grundpåstanden i den del af "The Neglected Argument for the Reality of God", som Peirce kalder PA (the Practical Aspect), er kort sagt, dels at musement over antagelsen om Gud som nødvendig væren (ens necessarium), universets skaber og opretholderen af den kontinuitet, der er nødvendig for, at mennesket kan forstå den verden, det bebor, vil resultere $\mathrm{i}$, at den, der er engageret i musement, vil ændre sin handlemåde og adfærd. For det andet, at en sådan ændret handlemåde eller adfærd ikke kan adskilles fra tro på (eng. belief in) Gud:

Any normal man who considers the three Universes in the light of
God's Reality, and pursues that line of reflection in scientific singleness
of heart, will come to be stirred to the depths of his nature by the idea
and by its august practicality, even to the point of loving and adoring
his strictly hypothetical God, and to that of desiring above all things to
shape the whole conduct of life and all the springs of action into con-
formity with that hypothesis. Now to be deliberately and thoroughly
prepared to shape one's conduct into conformity with a proposition is
neither more nor less than the state of mind called Believing that pro-
position (EP 2, 439).

I sit efterskrift kalder Peirce denne anden del af sit essay for det egentligt oversete argument. Han opfatter altså kernen i "The Neglected Argument for the Reality of God" som et trosbegreb, hvis mening eller betydning skal findes i den praksisform, som det medfører. Korresponderende med denne opfattelse definerer Peirce i det foregånde citat ikke tro som noget rent intellektuelt, men som en måde at forme sin handlemåde således, at den er i overensstemmelse med et begreb (eng. proposition). At 'tro' på the Humble Argument er altså at forme sin handlemåde således, at den er i overensstemmelse med the Humble Argument. Det er i disse termer, det skal forstås, når Peirce $\mathrm{i}$ essayets anden del påstår, at engagement i the Humble Argument er uadskilleligt fra tro på hypotesen om Gud. Peirces begreb om tro (belief) indskrives således i en art talehandlingsteori (eller bedre: en teori om kommunikativ handlen), en pragmatisk (eller med Peirces ord pragmaticistisk) måde at forstå forholdet mellem betydning og tro.

Således berører $P A$ det helt centrale tema i essayet, og det bliver nu tydeligt, hvorfor Peirce kalder denne del af sin argumentation for den egentligt oversete. Hvis man vil forstå Peirce derhen, at han forsøger at argumentere for Guds eksistens ud fra et korrespondensprincip, giver argumentationen ingen logisk mening. Hvis man derimod tager Peirce på ordet og læser essayet som et pragmatisk argument for Guds virkelighed, så stiller sagen sig anderledes: Ligesom det at gøre brug af fysik nødvendigvis implicerer troen på en ydre verden, eller det, at man i sine handlinger gør brug af moral, indebærer en tro på 
begreber som godt og slet, således indebærer den praksis, som det er at gøre brug af musement over gudshypotesen, nødvendigvis en bekræftelse af Guds virkelighed. Grunden til, at Peirces argument er overset er, ifølge Peirce selv, at teologerne (som er den gruppe 'videnskabsmænd', der har beskæftiget sig med at konstruere udsagn om Gud) historisk set har været mere interesserede i at cementere den dogmatisk rette lære i stedet for at udvikle falcificeringer af deres egne trossætninger. ${ }^{18}$ Hvis teologerne derimod beskæftigede sig med teologien på en måde, som var nysgerrig og åben over for dens erkendelsesobjekt (Gud) og ikke dogmatisk lukket om sig selv og optaget af at udstøde "vranglærere", så ville de, ifølge Peirce, før eller siden støde på the Humble Argument og overbevises om argumentets kraft på en sådan måde, at de ville gøre det til centrum for deres teologiske udforskning (EP 2, 446).

\section{Det logiske aspekt}

Den tredje og sidste del af "The Neglected Argument for the Reality of God" fremhæver den logiske metodologi ("logical methodeutic") af the Humble Argument ${ }^{19}$. Det vil kort sagt sige, at den del af sit essay, som Peirce kalder $L A$ (the Logical Aspect) har at gøre med, hvilken status, man kan tilkende the Humble Argument som logisk hypotese. For det første siger Peirce her, at den logiske metodologi, der ligger bag the Humble Argument, ligner den logiske metodologi, der ligger bag det første trin af enhver videnskabelig undersøgelse (EP 2, 447). Peirce ser således ikke sin hypotese om Guds virkelighed som uforenelig med videnskabelige hypoteser, men han ser ikke desto mindre en vigtig forskel: Denne forskel er, at hvor videnskabelige hypoteser normalvis udvikles trefoldigt gennem abduktion, deduktion og induktion, så bevæger gudshypotesen sig ikke ud af det abduktive stadium, fordi den finder sted i musement. Idéen om, at de tre 'universer' må være en nødvendig værens frembringelse, er altså en abduktion: En forklarende hypotese, hvis opgave det er at besvare, hvorfor skønhed og kontinuitet er en del af universet. Endvidere viser det ovenstående citat, at Peirce ikke definerer videnskab som akkumulation af viden om et bestemt emne, men som et spørgsmål om metode.

18. Se Charles Sanders Peirce, Collected Papers Volume 6, red. Charles Hartshorne og Paul Weiss (Cambridge: Harvard University Press 1934), \$1-6.

19. Peirce definerer 'methodeutic' som den disciplin der "studies the methods that ought to be pursued in the investigation, in the exposition, and in the application of truth” (CP I \$191). 
Den anden del af $L A$ er en kursorisk refleksion over forholdet mellem essayets tre dele. Peirce ekspliciterer her, at "The Neglected Argument for the Reality of God" ikke har til hensigt at isolere the Humble Argument. Essayets argumentation er afhængig af alle tre trin, og læser man det isoleret, er the Humble Argument utilstrækkeligt:

the Plausibility of the hypothesis reaches an almost unparalleled height among deliberately formed hypotheses. So hard is it to doubt the God's Reality, when the Idea has sprung from Musements, that there is great danger that the investigation will stop at this first stage, owing to the indifference of the Muser to any further proof of it. At the same time, this very Plausibility is undoubtedly an argument of no small weight in favor of the truth of the hypothesis (EP 2, 447).

Relationen mellem de tre dele af "The Neglected Argument for the Reality of God"

Det er til stadighed omdiskuteret i Peirce-forskningen, hvordan den indbyrdes relation mellem de tre dele af "The Neglected Argument for the Reality of God" skal konciperes. Douglas R. Anderson har overbevisende argumenteret for, at ingen indtil videre er kommet til et tilfredsstillende svar på, hvordan man skal forstå de tre deles 'organiske interdependens' ("organic interdependence") (Anderson, 1990, 349). Forskningen har i stedet haft en tendens til at reducere de tre dele til to grupper, som regel med den konsekvens, at man har nedtonet betydningen af essayets anden del, $P A$. Denne del er dog, som vi har set, ironisk nok den del, som Peirce selv opfatter som det egentligt oversete argument. ${ }^{20}$ Desuden kunne vi i forlængelse af Anderson tilføje, at det er bemærkelsesværdigt (for at sige det mildt), at Peirces idé om synechisme som regel har været nedtonet i tolkninger af "The Neglected Argument for the Reality of God". For at løse dette problem forsøger Anderson at forbinde essayets tre dele med Peirces person-kategoriologi ("categoriology of persons"). ${ }^{21}$

Denne treleddede person-kategoriologi er imidlertid blot ét udslag af Peirces overordnede teori om førstehed, andethed og tredjehed, og i det følgende vil jeg overføre et andet udslag af denne teori til en læs-

20. Anderson refererer her til læsningerne af argumentet hos John E. Smith, Richard Trammell, Mary Mahowald, Bowman L. Clarke, and Vincent Potter. Kort sagt de forskere, som før 1980'erne havde beskæftiget sig mest indgående med essayet. Se Anderson, 1990, 349.

21. Med dette forstår Anderson $(1990,351)$ følgende: "These, which Peirce says he obtained by way of Kant, are Feeling, Willing (acting and undergoing), and Thinking (knowing)". 
ning af sammenhængen mellem de tre dele af "The Neglected Argument for the Reality of God". Et udslag, som jeg finder endnu mere frugtbart som løsning på det af Anderson identificerede problem. Hermed er det mit mål at opnå to ting: For det første vil jeg vise, at essayets organiske interdependens træder frem, hvis man læser "The Neglected Argument for the Reality of God" inden for rammerne af Peirces overordnede semiotiske system. En sådan framing gør Peirces intention med sit argument mindre enigmatisk og dunkel, idet den viser, at argumentationsgangen i essayet er fuldt kompatibel med den sene Peirces øvrige tankeverden. For det andet ønsker jeg at betone den synechisme, jeg mener, er central for essayets sammenhæng: Argumentets tre dele kan ikke forstås uafhængigt, men implicerer med logisk nødvendighed hinanden.

I essayet "Nomenclature and Triadic Relations as Far as The Are Determined" (EP 2, 289-300) fra 1903 arbejder Peirce med den teori, at betydningsdannelse altid involverer tre parter: "a cooperation of three subjects, such as a sign, its object, and its interpretant, this tri-relative influence not being in any way resolvable into actions between pairs". ${ }^{22}$ Denne fundamentale forståelse af, hvordan betydning opstår, er faktisk tilstrækkelig for at belyse alle aspekter af alle tegnrelationer. Den kan besvare, hvordan tegn henviser, hvilke slags tegn, objekter og interpretanter, der findes, hvordan forskellige tegn forbindes med hinanden og hvordan tegn kan indoptage eller inkarnere andre tegn. Det er således denne generiske definition af betydningsskabelse, der ligger bag det væld af klassifikationer af semiotiske elementer, som Peirce udviklede i sit sene forfatterskab, og af hvilke opdelingen af tegn i indexikale, ikoniske og symbolske tegn er den mest udbredte. ${ }^{23}$

Som de til stadighed genkommende triadiske strukturer viser, så er Peirces semiotik et udslag af hans metafysiske doktrin om førstehed, andethed og tredjehed. Han påstår således, at "Triadic relations are in three ways divisible by trichotomy, according as the First, the Second, or the Third Correlate, respectively, is a mere possibility, an actual existent, or a law. These three trichotomies, taken together, divide all triadic relations into ten classes". ${ }^{24}$ En af disse triadiske relationer er relationen mellem tegnene Rheme, Dicisign og Argument. Umiddelbart har denne klassifikation en interesse for den nærværende fremstilling, fordi Peirce netop kalder sit essay for et argument for Guds

22. Således parafraseret af Nathan Houser i EP 2, 411.

23. Se EP 2, 289-292.

24. EP 2,290. En oversigt over Peirces tegnkategorier gives i øvrigt af Jesper Tang Nielsen, "The Secondness of the Fourth Gospel", Studia Theologica - Nordic Journal for Theology, 60 (2006), 123-144. 
virkelighed. Distinktionen mellem Rheme, Dicisign og Argument har at gøre med, hvordan et tegns interpretant opfatter tegnets måde at repræsentere sit objekt (EP 2, 296). I "Nomenclature and Divisions of Triadic Relations as Far as They Are Determined" beskrives et Argument-tegn som et tegn, der repræsenterer objektet ved lovmæssighed eller vane, og som derfor opfattes af repræsentanten som symbolsk (korresponderende til tredjehed). Argument-tegnets symbolske karakter betyder, at det giver anledning til endnu en triadisk tegndeling, nemlig mellem Argument, Premiss og Conclusion:

The Interpretant of the Argument represents it as an instance of a general class of arguments, which class on the whole will always tend to the truth. It is this law, in some shape, which the argument urges; and this 'urging' is the mode of representation proper to arguments. The Argument must, therefore, be a Symbol, or sign whose Object is a general law or type. It must involve a Dicent Symbol, or Proposition, which is termed its Premiss (...) As for another proposition, called the Conclusion, often stated and perhaps required to complete the Argument, it plainly represents the Interpretant, and likewise has a peculiar force, or relation to the Interpretant (EP 2, 293).

Hvis vi overfører den triadiske beskrivelse af Argument-tegnets indre sammenhæng, så har vi her en metode til at belyse sammenhængen mellem de tre dele af Peirces argument for Guds virkelighed. Beskrivelsen af Argument-tegnet som bestående af selve Argument-tegnet, et præmis-tegn (Premiss) og et konklusion-tegn (Conclusion) kan illustreres således:

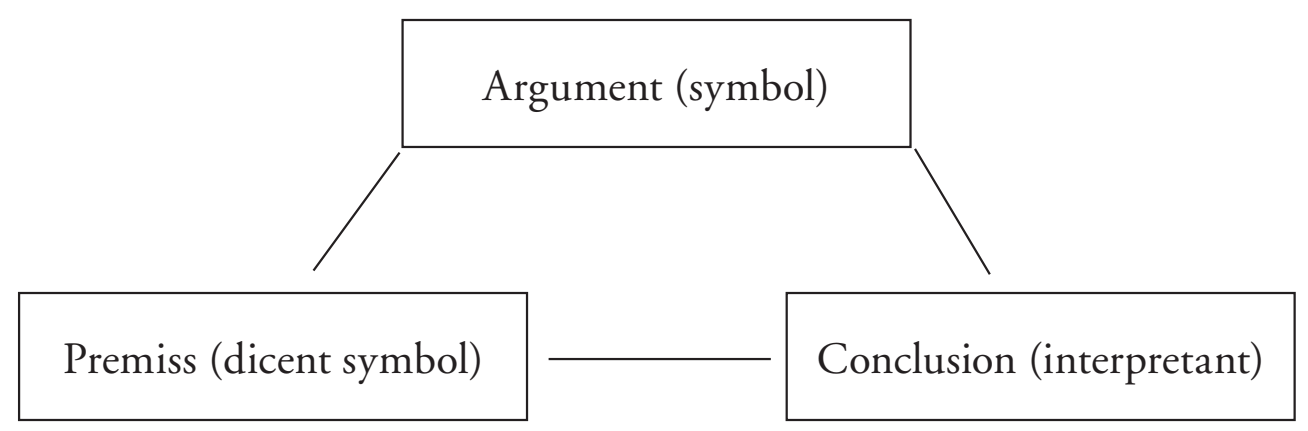

Vi har allerede været inde på, at selve Argument-tegnet repræsenterer sit objekt for sin interpretant som et symbol (en vane eller lovmæssighed). Dette korresponderer med Peirces beskrivelse af the Humble Argument: For det første, så bliver the Humble Argument, som vi har set, beskrevet som et generelt begreb (eng. notion), der indikerer en tankeproces, der nærmer sig en bestemt overbevisning (i modsætning til en argumentation, der leder fra eksplicit formulerede præmisser til 
en eksplicit konklusion). For det andet, så bliver the Humble Argument beskrevet som den centrale del af argumentet, til hvilken de to andre dele knytter sig som argumentationer. The Humble Argument er altså det, der binder Peirces argument for Guds virkelighed sammen, og det, der initierer den proces, som argumentet udgør.

I det foregående citat blev Conclusion-tegnet beskrevet som det, der repræsenterer interpretanten. Interpretanten er som sagt den praktiske konsekvens af tegnlæsningsakten, hvilket gør det oplagt at identificere den anden del af Peirces essay, PA, med Conclusion-tegnet. Endvidere kalder Peirce som sagt denne del af sit essay for det egentligt oversete argument, og den vigtighed, som Peirce dermed tilskriver $P A$, korresponderer godt med hans generelle betydningsteori, hvor en af grundpåstandene jo er, at mening eller betydning ikke er noget, der udspiller sig mellem tegn og objekt, men opstår i interpretantens aflæsning af dette forhold. Identifikationen af Argument-tegn og the Humble Argument og Conclusion-tegnet med the Practical Aspect betyder, at Premiss-tegnet svarer til den tredje del af argumentet, $L A$. Her er parallellen måske ikke helt så åbenlys som i de to foregående tilfælde. Imidlertid udgør $L A$ en eksplicitering eller beskrivelse af argumentets logiske status, og man kan derfor med god ret sige, at $L A$ qua sin eksplicitering konstituerer argumentets præmis. Den her foreslåede parallel mellem Argument-tegnets indre natur og strukturen i "The Neglected Argument for the Reality of God" kan illustreres således:

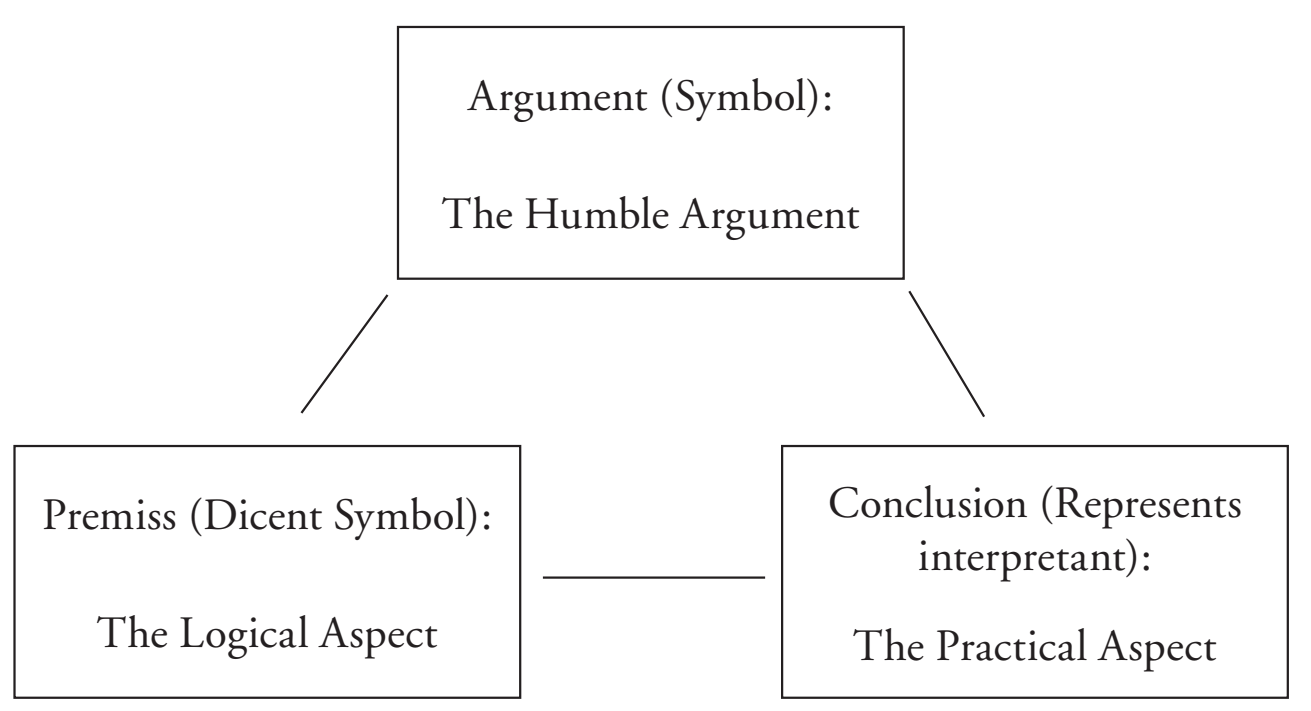

Denne måde at fortolke strukturen i Peirces argument har (mindst) to fordele: For det første viser parallellen, at der ikke er sagligt grundlag for den stedmoderlige behandling, som "The Neglected Argu- 
ment for the Reality of God" har haft i Peirce-forskningen: Når essayet kan analyseres ved hjælp af Peirces generelle betydningslære, er det fordi argumentet trækker på de samme semiotiske konceptioner som Peirces øvrige senværk. Ved således at revurdere betydningen af "The Neglected Argument for the Reality of God" inden for det værk og den tankeverden, den er en integreret del af, mindskes den kryptiske karakter, som så ofte er blevet tilskrevet argumentet, og Peirces eksakte intention med essayet træder tydeligere frem. For det andet borger min tolkning af essayets struktur for en forståelse for den organiske afhængighed argumentets tre dele eller stadier imellem. De tre dele hører sammen med logisk nødvendighed, og fjerner man en af de tre dele, har argumentet ingen mening. Med Peirces egne ord: "Premise and interpretant (conclusion) are essential to the full expression of the argument" (EP 2, 293).

\section{Afsluttende perspektivering: Peirce og naturalismen}

I det følgende vil jeg på baggrund af "The Neglected Argument for the Reality of God" skitsere det teologiske potentiale i Peirces essay ved at perspektivere til, hvordan Peirces gudsbegreb bringer diskussionen om den metodologiske naturalismes filosofiske validitet ind på religionsfilosofiens område. ${ }^{25}$ Dette viser sig, hvis man bruger Peirces pointer i diskussionen om forholdet mellem metodologisk naturalisme og normativ viden. ${ }^{26}$

Først vil jeg i grove træk skitsere de to former for naturalisme, som dominerer tidens debat: Ontologisk naturalisme og metodologisk naturalisme. Efter denne brede introduktion vil jeg fokusere snævert på diskussionen om forholdet mellem metodologisk naturalisme og normativitet for til sidst at vise, at denne diskussion på baggrund af "The Neglected Argument for the Reality of God" får en religionsfilosofisk dimension.

25. Den videnskabelige og filosofiske naturalisme har i de senere år har tiltrukket forskningsopmærksom i teologiske kredse. Eksempelvis har Det Teologiske Fakultet ved Københavns Universitet et Centre for Naturalism and Christian Semantics, hvis hidtidige forskningsresultater foreligger i Essays in Naturalism and Christian Semantics, red. Niels Henrik Gregersen og Troels Engberg-Pedersen (København: Det Teologiske Fakultet, Københavns Universitet 2010).

26. Jeg skylder manuskriptets anonyme læser tak for at have påpeget, at det nødvendigvis er i denne retning, nærværende undersøgelse måtte gå. 


\section{To slags naturalisme}

David Papineau kalder i sin artikel "Naturalism" 27 i The Stanford Encyclopedia of Philosophy det umuligt at give en fuldstændig fyldestgørende definition af det væld af positioner, som termen ontologisk naturalisme dækker over: "It would be fruitless to try to adjudicate some official way of understanding the term [ontological naturalism]. Different contemporary philosophers interpret 'naturalism' differently". Imidlertid deler de forskellige former for ontologisk naturalisme den forestilling, at virkeligheden ikke har behov for noget eksternt ontologisk grundlag, og at den naturvidenskabelige metode derfor dækkende kan forklare alle områder af virkeligheden: "reality is exhausted by nature, containing nothing 'supernatural', and that the scientific method should be used to investigate all areas of reality, including the "human spirit". Denne tanke får en metodologisk dimension i den såkaldt metodologiske naturalisme. Ifølge David Papineau ser metodologiske naturalister filosofien og videnskaben som engagerede i fundamentalt set den samme undersøgelse. Målene er ens, og det samme bør metoderne være.

\section{Metodologisk naturalisme og normativitet}

En tendens til metodologisk naturalisme er udbredt i mange filosofiske miljøer. Disse overser imidlertid, ifølge Papineau, at denne position har en blind plet: Den metodologiske naturalisme forholder sig ikke til, at filosofien (også) har en normativ dimension. Visse dele af filosofien; etikken, den politiske filosofi og æstetikken, forholder sig eksplicit til normative problemstillinger. I kontrast hertil ses de empiriske videnskabers primære opgave som den at arbejde med deskriptive forskningsresultater. Disse forskningsresultater kan indeholde normative implikationer, men behøver ikke at gøre det.

På det grundlag er det urimeligt at påstå, at de grene af filosofien, der arbejder med normativ viden, skulle gøre brug af de samme videnskabelige metoder som de empiriske videnskaber. Som modargument hertil kan tilhængere af metodologisk naturalisme gøre gældende, at metaetikken (og metanormativitet generelt set) i egentlig forstand er en gren af metafysikken og derfor ikke udgør noget nyt argument imod naturalismen Når filosoffer undersøger moralsk eller æstetisk værdi og analyserer strukturen af moralske eller æstetiske diskur-

27. Papineau, David, "Naturalism", The Stanford Encyclopedia of Philosophy (Spring 2009 Edition), red. Edward N. Zalta, URL = http://plato.stanford.edu/ archives/spr2009/entries/naturalism/ 
ser, så er deres mål at finde ud af, hvilke fakta verden indeholder og hvordan mennesker forholder sig til disse fakta. Hvis metafysiske undersøgelser generelt kan forstås metodologisk naturalistisk, så er der ingen grund til at antage, at metanormativ filosofi ikke kan forstås tilsvarende. Alligevel gælder dette svar, ifølge Papineau, kun et stykke ad vejen. Metanormative undersøgelser eller overvejelser udgør visse dele af filosofiens normative områder, men det er ikke korrekt at hævde, at de udtømmer disse områder. Filosoffer forholder sig ligesom andre mennesker også til diskussioner af første orden (altså ikke-meta teoretisering): Moralfilosoffer diskuterer fx retten til abort, dødsstraf osv. Politiske filosoffer deltager i debatter om, hvornår eksterne aktører kan tillade sig at invadere nationalstater og hvorvidt frihedsrettigheder er universelle. Æsteter diskuterer vigtigheden af originalitet og værdien af konceptkunst osv. Pointen er, at hvis normativ filosofi var begrænset til metanormative problemstillinger, så ville den være langt mindre interessant og have langt mindre betydning. Denne problemstilling fører ifølge Papineau til en diskussion om grundlaget af normative domme. Her mener han ikke, at det giver mening at hævde, at normative domme er formet på en måde, som har en parallel $\mathrm{i}$ videnskabelige undersøgelser. Normative domme må som grundlag have menneskelige reaktioner af emotionel eller motiverende art. Som modargument hertil vil filosoffer med metodologisk naturalistiske tilbøjeligheder, ifølge Papineau, kunne gøre gældende, at selvom det ovenstående skulle være sandt, så vil ingen anvendelig teori om normativitet kunne antage idéen om, at en del af virkeligheden er naturalistisk uforklarlig. Dette er ifølge Papineau et gangbart modargument. Diskussionen om forholdet mellem metodologisk naturalisme og normativitet rejser dog et yderligere problem, nemlig spørgsmålet om, hvorvidt normative problemer af første orden (altså ikke-metanormative problemer) løses ved brug af de samme metoder, som bliver brugt i de empiriske videnskaber? Svaret på det spørgsmål er ifølge Papineau nej.

Endvidere kunne filosoffer af naturalistisk overbevisning gøre gældende, at sådanne normative problemer af "første orden" finder sted i lige så høj grad uden for filosofien som indenfor. Man vil i forlængelse heraf holde på, at der ikke findes nogen distinkt metode, der er forbeholdt filosofien. Dette medgiver Papineau. Men det godtgør ikke den metodologiske naturalisme. For den metodologiske naturalist hævder ikke blot, at filosofien deler sin metode (eller sine metoder) med andre måder at forholde sig til verden på. Den hævder, at filosofien deler (eller rettere: altid bør dele) sine metoder med naturvidenskaberne. Derfor er det ikke et argument til fordel for den metodologiske naturalisme at hævde, at den deler sin normative praksis af "første orden" 
med ikke-videnskabelige foretagender som æstetisk teori og politisk debat.

\section{Gudsbegrebets normativitet}

På baggrund af ovenstående redegørelse vil vi afsluttende kunne se, at Peirces gudsbegreb bringer denne diskussion ind på religionsfilosofiens område. David Papineau hævder i sin redegørelse om forholdet mellem den metodologiske naturalisme og normativ viden, at det afgørende argument imod den metodologiske naturalisme er, at normative slutninger træffes på grundlag af en menneskelig respons, som kan være af emotionel eller motiverende art: "normative judgements must [be] grounded in characteristic human responses of an emotional or motivating kind" (ibid).

Det vil sige, at menneskets omgang med verden er baseret på eksterne faktorer, der har normativ betydning, selvom de ikke nødvendigvis har konkret eksistens, altså ikke er til at tage og føle på.

Vi så i gennemgangen af Peirces essay, at gudsbegrebet hos Peirce netop udgør en i forhold til mennesket ekstern instans, som har en motiverende betydning. Gudsbegrebets distinkte normativitet er simpelthen immanent, fordi Gud (som er abstrakt eller generel) har en realitet, som mennesket - i musement - regulerer sin adfærd i forhold til. Peirces gudsbegreb udgør således et normativt grundlag i Papineaus forstand. Et grundlag, om hvis konkrete eksistens, der ikke kan udkastes falcificérbare udsagn, men som ikke desto mindre er formende for menneskets handlen, hvorfor Peirces gudsbegreb udgør et korrektiv til eller problem for den metodologiske naturalisme. 